\title{
FORMULASI DAN UJI AKTIVITAS ANTIBAKTERI SEDIAAN KRIM EKSTRAK KULIT BATANG MANGROVE (Avicennia marina) TERHADAP PERTUMBUHAN Staphylococcus aureus
}

\author{
Wahyu Ade Setiawan ${ }^{1,}$ Lulu Setiyabudi $^{* 2}$, Asep Nurrahman Yulianto ${ }^{3}$ \\ 1,*2,3 Program Studi Sarjana Farmasi STIKES Al-Irsyad Al-Islamiyyah, Cilacap, Jawa Tengah, Indonesia \\ e-mail : ${ }^{1}$ wahyuades172@gmail.com. ${ }^{* 2} 1$. setiyabudi@gmail.com, ${ }^{3}$ nurrahmanasep@yahoo.co.id
}

\begin{abstract}
ABSTRAK
Penyakit menular yang disebabkan oleh bakteri Staphylococcus aureus dapat menyebabkan infeksi ditandai dengan kerusakan jaringan dengan abses. Mangrove Avicennia marina memiliki senyawa seperti alkaloid, flavonoid, fenol, terpenoid, steroid dan saponin yang disebut metabolit sekunder, senyawa ini efektif digunakan sebagai anti bakteri. Penelitian dilakukan dengan metode eksperimental bertujuan untuk mendapatkan formulasi krim ekstrak kulit batang mangrove A. marina dengan variasi komposisi jumlah propilenglikol. Hasil penelitian ini menunjukan bahwa ekstrak kulit batang mangrove dan sediaan krim ekstrak kulit batang mangrove Avicennia marina terdapat aktivitas antibakteri Staphylococcus aureus. Zona hambat sediaan krim ekstrak kulit batang masngrove Avicennia marina yaitu formulasi 1, 2 dan 3 memiliki rata-rata zona hambat yang sama yaitu sebesar $25 \mathrm{~mm}$ terhadap pertumbuhan Staphylococcus aureus. Kemudian hasil uji sifat fisik yaitu pada uji organoleptis dari ketiga formulasi memiliki warna, bau dan bentuk yang sama. Hasil uji homogenitas, uji viskositas dan uji pH sediaan dari ketiga sediaan memenuhi persaratan. Sedangkan pada uji daya sebar dan uji daya lekat tidak sesuai setandar.
\end{abstract}

Kata Kunci : Antibakteri, Avicennia marina, Staphylococcus aureus.

\begin{abstract}
An Infectious disease caused by Staphylococcus aureus bacteria can cause infection characterized by tissue damage with abscesses. Mangrove Avicennia marina has compounds such as alkaloids, flavonoids, phenols, terpenoids, steroids, and saponins called secondary metabolites, these compounds are effectively used as anti-bacterial. The research was conducted using an experimental method to obtain a formulation of A. marina mangrove bark extract cream with varying compositions of propylene glycol. The results of this study showed that the extract of the mangrove bark and the cream preparation of Avicennia marina mangrove bark extract contained the antibacterial activity of Staphylococcus aureus. Inhibition zones of Avicennia marina mangrove bark extract cream preparations, namely formulations 1, 2, and 3, had the same average inhibition zone of $25 \mathrm{~mm}$ against Staphylococcus aureus growth. Then the results of the physical properties test, namely the organoleptic test of the three formulations had the same color, smell, and shape. The results of the homogeneity test, viscosity test and $\mathrm{pH}$ test of the three preparations met the requirements. Meanwhile, the dispersion test and adhesion test did not match the standard.
\end{abstract}

Keywords: anti-bacterial, Avicennia marina, Staphylococcus aureus

\section{PENDAHULUAN}

Staphylococcus aureus adalah salah satu Patogen utama manusia yang dapat menyebabkan infeksi ditandai dengan kerusakan jaringan dengan abses. Infeksi yang disebabkan oleh $S$. aureus dapat terjadi secara langsung maupun tak langsung. Infeksi $S$. aureus dapat juga disebabkan oleh kontaminasi langsung pada luka. [1]. Salah satu tanaman yg dapat dipergunakan sebagai anti bakteri adalah Mangrove yang tumbuh di daerah pesisir. Salah satu jenis mangrove 
yang banyak dijumpai yaitu Avicennia marina atau mangrove Api-api. Dalam jurnal [2] mangrove A. marina terdapat senyawa seperti alkaloid, flavonoid, fenol, terpenoid, steroid dan saponin yang disebut metabolit sekunder. Menurut [3] pada bagian daun Avicennia marina mempunyai senyawa alkaloid sedangkan pada batang (steroid serta triterpenoid) serta akar (flavonoid). Kandungan senyawa yang berbeda dalam mangrove berperan penting dalam menopang kehidupan, salah satunya yaitu sebagai antibakteri.

Salah satu pemanfaatan tanaman mangrove Avicennia marina yaitu dengan cara mengambil ekstrak mangrove Avicennia marina dengan cara maserasi. Berdasarkan studi aktivitas ekstrak mangrove terhadap bakteri Staphylococcus aureus dan Eschericiacoli. Dapat disimpulkan bahwa bioaktivitas senyawa bioaktif jenis mangrove marina lebih tinggi dibandingkan dengan B. Gymnorrhiza terutama pada bagian daun (14,11 mm). ) Batang (25,28 $\mathrm{mm})$. ) Dan akar $(19,11 \mathrm{~mm})$ [3]. Bentuk sediaan topikal yang sekarang ini dikembangkan oleh industri farmasi dan kosmetik, serta beberapa lembaga penelitian yaitu sediaan krim. Krim merupakan sediaan topikal dengan bentuk semi padat yang cocok untuk pengobatan kulit seperti luka pada kulit, gatal-gatal, menghilangkan bekas luka atau noda pada kulit. Pada penggunaan krim umumnya lebih disukai sebab krim lebih mudah dioleskan, dan lebih mudah dibilas [4].

\section{METODE PENELITIAN}

\subsection{Alat dan Bahan}

Alat yang digunakan pada penelitian ini yaitu Neraca analitik Ohauss (PioneerTM $®$ ), Alat - alat gelas (Pyrex $\left.\AA^{\circledR}\right)$, Pisau, Oven (Memmert $\left.{ }^{\circledR}\right)$, Blender (Miyako®), Ayakan, Bejana, Kain flanel, Kertas saring, Penangas air, Desikator (Iwaki ${ }^{\circledR}$ ), Mortir, stampher, Sudip, Wadah krim,Viskometer, Autoklaf (GEA model YX-18LM), Iinkubator (Memmert@), Cawan petri, Jarum ose, Bunsen, Kompor listrik (Maspion $\left.{ }^{\circledR}\right)$, Vorteks (VM-300), Tabung reaksi (Pyrex®), Yellow tip (Onemed $\left.{ }^{\circledR}\right)$, Mikro pipet (Socorex), pH meter (Neschgo®), Ekstensometer, Anak timbangan.

Bahan yang digunakan adalah kulit batang mangrove A. marina,Cera Alba (Malam putih) (Brataco®), Asam stearat(Brataco®), Vaselin Flavum (Vaselin kuning)(Brataco $\left.{ }^{\circledR}\right)$, Trietanolamin (TEA)(Brataco $\left.{ }^{\circledR}\right), \quad$ Propilen glikol(Brataco $\left.{ }^{\circledR}\right), \quad$ Metil paraben (Nipagin)(Brataco $\left.{ }^{\circledR}\right), \quad$ Aquadest $\left(\right.$ Brataco $\left.{ }^{\circledR}\right), \quad$ Etanol $\quad 96 \%\left(\right.$ Brataco $\left.{ }^{\circledR}\right), \quad$ Krim Chloramphenicol,Kertas Cakram, Media NA(Nutrient Agar), Bakteri S. aureus, Natrium Clorida0,9\% $(\mathrm{NaCl} 0,9 \%)$ Asam Sulfat $\left(\mathrm{H}_{2} \mathrm{SO}_{4}\right)\left(\right.$ Brataco $\left.{ }^{\circledR}\right)$, Asam Asetat $\left(\mathrm{CH}_{3} \mathrm{COOH}\right)\left(\right.$ Brataco $\left.{ }^{\circledR}\right)$, Kloroform $\left(\right.$ Brataco $\left.{ }^{\circledR}\right)$, Asam Klorida $(\mathrm{HCl})\left(\right.$ Brataco $\left.{ }^{\circledR}\right)$, Reagen Dragendroff, Logam Magnesium(Logam Mg).

\subsection{Jalannya Penelitian}

\subsubsection{Preparasi Sampel}

Sampel diambil dari salah satu wilayah di Kabupaten Cilacap, Jawa Tengah. Kulit batang mangrove A. marina yang diambil yaitu berwarna coklat yang sudah tua dari bagian batang pohon atau bagian tangkai batang pohon. Sampel selanjutnya dilakukan uji determinasi tanaman. 


\subsubsection{Pembuatan Ekstrak Kulit Batang Mangrove A. marina}

Sampel diekstraksi dengan pelarut etanol 96\%. Sampel kulit batang mangrove A. marina yang telah dibersihkan dan disortir ditimbang sebanyak $500 \mathrm{~g}$, dimasukan kedalam wadah maserasi, kemudian ditambahkan etanol 96\% dengan perbandingan (1:3, b/v) selama $2 \mathrm{X}$ 24 jam pada suhu ruangan, dan dilakukan remaserasi sebanyak 1 kali. Kemudian hasil ekstrak diuapkan untuk menghilangkan pelarut etanol 96\% dengan menggunakan waterbath dengan suhu $60^{\circ} \mathrm{C}$ sampai diperoleh ekstrak kental.

\subsubsection{Penetapan Kadar Air}

Sebanyak 1 gram ekstrak kulit batang mangrove A. marina diletakan pada kertas saring kemudian dikeringkan dengan oven pada suhu $105^{\circ} \mathrm{C}$ Selama 60 menit. Hasil pengeringan ditimbang dan dihitung berat kertas saring sebelum dan sesudah dikeringkan.

\subsubsection{Uji Bebas Etanol Ekstrak Kulit Batang Mangrove A.marina}

Uji bebas etanol ekstrak etanol kulit batang mangrove A. marina, dilakukan dengan menggunakan metode esterifikasi etanol, dengan cara diambil $1 \mathrm{~g}$ ekstrak kulit batang mangrove A. marina lalu dimasukkan kedalam tabung reaksi ditambahkan $1 \mathrm{~mL}$ asam asetat dan $1 \mathrm{~mL}$ asam sulfat pekat kemudian dihomogenkan dan dipanaskan diatas bunsen, atas tabung ditutup dengan kapas, ekstrak telah bebas etanol ditandai dengan tidak timbulnya bau ester yang menguap selama proses pemanasan [5].

\subsubsection{Skrining Fitokimia Ekstrak Kulit Batang Mangrove A. marina}

\section{a. Uji Alkaloid}

$5 \mathrm{ml}$ ekstrak kulit batang mangrove A. marina ditambahkan dengan $2 \mathrm{~mL} \mathrm{HCl}$ kemudian ditambahkan Reagen Dragendorff. Ekstrak yang positif mengandung alkaloid akan menunjukkan warna orange atau merah pada presipitat [5].

b. Uji Flavonoid

Ekstrak kulit batang mangrove A. marina sebanyak $1 \mathrm{mg}$ dimasukan ke dalam tabung reaksi, setelah itu ditambahkan logam $\mathrm{Mg}$ dan 4-5 tetes $\mathrm{HCl}$ pekat. Larutan berwarna merah atau jingga yang terbentuk menunjukan adanya flavonoid [5].

c. Uji Steroid Dan Terpenoid

Ekstrak kulit batang mangrove A. marina dilarutkan dalam kloroform kemudian ditambahkan pereaksi $\mathrm{H}_{2} \mathrm{SO}_{4}$ secara pelan dan hati-hati,menunjukan hasil positif dengan adanya perubahan warna menjadi merah kecoklatan untuk steroid dan coklat ungu untuk triterpenoid [5].

d. Uji Fenol

5ml Ekstrak kulit batang mangrove A. marina dilarutkan dalam air dan direaksikan dengan $\mathrm{FeCl} 3$ 1\% menunjukan hasil negatif dengan tidak adanya perubahan warna menjadi hijau kehitaman [6].

e. Uji Saponin

Ekstrak kulit batang mangrove A. marina dimasukan dalam tabung reaksi kemudian dikocok. uji saponin tidak menunjukkan hasil positif karena buih yang terbentuk setelah pengocokan tidak bertahan lama, hanya bertahan beberapa detik [7].

\subsubsection{Uji Aktivitas Antibakteri Ekstrak Kulit Batang Mangrove A. marina}

a. Penyiapan Alat Dan Sterilisasi

Beker glass, gelas ukur, erlenmeyer dan karet pipet yang sudah dibungkus, disterilkan terlebih dahulu di dalam autoklaf pada suhu $121^{\circ} \mathrm{C}$ selama 15 menit, dan alat-alat seperti batang pengaduk, pinset, spatula, gelas arloji yang sudah dibungkus dimasukkan dalam oven pada suhu $160-170^{\circ} \mathrm{C}$ selama \pm 2 jam, jarum ose dan pinset dibakar dengan pembakaran diatas api bunsen [5]. 


\section{b. Pembuatan Media NA (Nutrient Agar)}

Sebanyak 7, 25 gram nutrient agar disuspensikan dalam $250 \mathrm{~mL}$ aquades steril, kemudian dimasukan kedalam labu erlenmeyer dipanaskan menggunakan hotplate selama \pm 10 menit hingga larut. Kemudian disterilkan dengan autoklaf pada suhu $121^{\circ} \mathrm{C}$. Media yang sudah steril, dituangkan dalam kondisi hangat $\left(40^{\circ} \mathrm{C}-45^{\circ} \mathrm{C}\right)$ ke dalam cawan petri. Media nutrien agar yang telah dituangkan ke dalam cawan petri dibiarkan hingga memadat.

c. Pembuatan Kertas Cakram

Dilakukan dengan cara merendm kertas cakram yang berdiameter $6 \mathrm{~mm}$ kedalam ekstrak kulit batang mangrove A. marina pada Konsentrasi yaitu, $2 \%, 4 \%, 6 \%, 8 \%$, $10 \%$, kontrol negatif (etanol 96\%) dan kontrol positif (injeksi chloramphenicol)

\section{d. Uji Aktivitas Antibakteri Ekstrak Kulit Batang Mangrove A. marina}

Pada media NA yang telah padat dan sudah digoreskan bakteri $S$. aureus selanjutnya kertas cakram yang telah mengandung ekstrak kulit batang mangrove $A$. marina dan kontrol negatif serta kontrol positif ditempatkan pada permukaan media tepat diatas koloni. Masing-masing diatur jaraknya antar kertas cakram dalam cawan petri, selanjutnya diinkubasi pada suhu $37^{\circ} \mathrm{C}$ selama $24 \mathrm{jam}$. Setelah itu diukur diameter zona bening yang terbentuk disekitar kertas cakram tersebut.

\subsubsection{Formulasi Sediaan Krim Ekstrak Kulit Batang Mangrove $A$. marina a. Formulasi Krim}

Tabel I. Formulasi Krim Ekstrak Kulit Batang Mangrove A. marina

\begin{tabular}{llll}
\hline \multirow{2}{*}{ Bahan } & \multicolumn{3}{c}{ Konsentrasi Formula (b/v) } \\
\cline { 2 - 4 } & \multicolumn{1}{c}{ Formula } & \multicolumn{1}{c}{ Formula } & \multicolumn{1}{c}{ Formula } \\
& \multicolumn{1}{c}{$\mathbf{2}$} & $\mathbf{3}$ \\
\hline Ektrak A. marina(\%) & $\mathrm{x}$ & $\mathrm{x}$ & $\mathrm{x}$ \\
Cera Alba (g) & 2 & 2 & 2 \\
Asam Stearat (g) & 15 & 15 & 15 \\
TEA (g) & 1,5 & 1,5 & 1,5 \\
Vaselin Flavum (g) & 8 & 8 & 8 \\
Metil Paraben (g) & 0,12 & 0,12 & 0,12 \\
Propilen Glikol (g) & $\mathbf{4}$ & $\mathbf{6}$ & $\mathbf{8}$ \\
Aquadest (ml) & ad.100 & ad.100 & ad.100 \\
\hline
\end{tabular}

Keterangan : Pada ekstrak kulit batang mangrove A. marina jumlah bahan F1, F2, F3 belum tercantum (X), jumlah bahan ekstrak kulit batang mangrove A. marina ditentukan dari hasil uji aktivitas antibakteri ekstrak kulit batang mangrove A. Marina.

\section{b. Pembuatan Sediaan Krim}

Formulasi sediaan krim dapat dilihat pada Tabel I. Pembuatan basis krim tipe M/A dilakukan sesuai dengan komposisi formula yang tertera pada Tabel dengan cara dimasukan dalam masing-masing cawan porselin. fase minyak (cera alba, asam stearat, dan vaselin flavum) dileburkan di atas penangas air pada suhu $75^{\circ} \mathrm{C}$, adapun fasa air (TEA dan propilen glikol) dileburkan pada suhu $75^{\circ} \mathrm{C}$. Fase air (campuran TEA dan propilen glikol) tersebut kemudian dimasukkan ke dalam lelehan cera alba, asam sterat, dan vaselin flavum, lalu diaduk hingga homogen dalam mortir hangat hingga terbentuk masa krim lalu tambahkan aquadest panas sebagai pelarut ke dalam mortir kemudian dihomogenkan. Selanjutnya campuran tersebut ditambahkan metil paraben sebagai pengawet. Setelah krim dingin kemudian tambahkan Ekstrak Kulit Batang mangrove $A$. marina aduk hingga homogen, setelah homogen kemudian krim dimasukan ke dalam 
wadah. Selanjutnya dilakukan uji tipe krim dan uji fisik krim ekstrak kulit batang mangrove A. marina [8].

\subsubsection{Evaluasi Karateristik Fisik Krim}

a. Uji Organoleptis

Tujuan pengujian secara organoleptis adalah untuk mengetahui penampilan fisik sediaan Krim. Evaluasi organoleptis meliputi pengamatan secara visual perubahanperubahan bentuk, bau dan warna pada sediaan krim pada suhu kamar $\left(25^{\circ} \mathrm{C}\right)$ [8].

b. Uji Homogenitas Krim

Krim diambil dari masing-masing formula secukupnya dan dioleskan pada plat kaca, diraba dan saat digosokkan massa krim harus menunjukkan susunan homogen yaitu tidak terasa adanya bahan padat pada kaca [9].

\section{c. Uji Daya Sebar}

Ditimbang 0,5 gram krim diletakkan di tengah alat (kaca bulat), kacabulat bagian atas ditimbang terlebih dahulu dan diletakkn diatas krim, biarkan selama 1 menit, diukur diameter krim yang menyebar (diambil panjang rata-rata diameter dari beberapa sisi), ditberi beban $50 \mathrm{~g}, 100$, g, $150 \mathrm{~g}$, dan $200 \mathrm{~g}$. Sebagai beban tambahan secara bertahap, setiap penambahan beban didiamkan selama 1 menit dan dicatat diameter krim yang menyebar. Cara diatas diulangi sebanyak 3 kali tiap fomulanya [9].

\section{d. Uji pH}

Pengukuran $\mathrm{pH}$ sediaan dilakukan menggunakan indikator universal, indikator universal dicelupkan ke dalam sediaan krim. Setelah tercelup dengan sempurna, amati perubahan warna pada indikator universal tersebut dan sesuaikan dengan spektrum warna pada alat.

\section{e. Uji Daya Lekat}

Krim diambil sebanyak 0,25 gram kemudian dioleskan pada sebuah plat kaca. Kedua plat ditempelkan sampai plat menyatu dan ditekan dengan beban seberat $1 \mathrm{~kg}$ selama 5 menit, setelah itu beban diambil. Waktu sampai kedua plat saling lepas dicatat, kemudian dilakukan pengulangan sebanyak 3 kali untuk masing-masing formula [9].

\section{f. Uji Viskositas}

Viskositas sediaan krim diukur menggunakan Viskometer Brookfield. Sediaan krim sebanyak \pm 200 gr dimasukkan ke dalam cup. Kemudian dipasang spindle ukuran 64 dan rotor dijalankan dengan kecepatan $10 \mathrm{rpm}$. Hasil viskositas dicatat setelah Viskometer menunjukan angka yang stabil [9].

\section{g. Uji Tipe Krim}

Untuk memastikan tipe krim yang dibuat sesuai dengan tipe krim yang diharapkan.

\subsubsection{Uji Aktivitas Antibakteri Ekstrak Kulit Batang Mangrove A. marina}

Uji aktivitas ekstrak kulit batang mangrove $A$. marina dilakukan langkah pertama yaitu penyiapan alat dan sterilisasi, selanjutnya pembuatan media NA (Nutrient Agar), serta pembuatan suspensi bakteri. Pada uji aktivitas antibakteri ekstrak metode yang digunakan yaitu metode sumuran dengan diameter $\pm 8 \mathrm{~mm}$ menggunakan alat blue-tipe pada nutrien agar yang sudah ditanami bakteri uji. Ektrak dibuat beberapa konsentrasi yaitu $2 \%, 4 \%$, $6 \%, 8 \%$, dan $10 \%$, kontrol negatif berupa sediaan krim tanpa zat aktif, kemudian kontrol positif berupa krim antibiotik gentamisin 0,1\%. Dimasukan ekstrak dan diinkubasi selama 24 jam pada suhu $37^{\circ} \mathrm{C}$ [1].

2.2.10. Uji Aktivitas Antibakteri Sediaan Krim Ekstrak Kulit Batang Mangrove A. marina

Pada uji aktivitas antibakteri sediaan krim ekstrak kulit batang mangrove A. marina sama halnya dengan uji aktivitas ekstrak kulit batang mangrove $A$. marina. Pada penelitian ini menggunakan 3 kelompok yaitu sediaan krim ekstrak kulit batang mangrove $A$. marina (F1, F2, F3), kontrol negatif berupa sediaan krim tanpa zat aktif, kemudian kontrol positif berupa krim antibiotik gentamisin $0,1 \%$, Metode uji antibakteri yang digunakan pada 
penelitian ini adalah difusi sumuran dengan diameter $\pm 8 \mathrm{~mm}$ menggunakan alat blue-tipe pada nutrien agar yang sudah ditanami bakteri uji. Dimasukan sediaan krim. Diinkubasi selama 24 jam pada suhu $37^{\circ} \mathrm{C}$ dan dilakukan pengukuran zona hambat dengan menggunakan jangka sorong [1].

\subsection{Analisis Data}

Analisis menggunakan metode analisis deskriptif, data yang didapatkan adalah data statistik deskriptif yaitu, untuk melihat kemampuan ekstrak kulit batang mangrove A. marina dan sediaan krim ekstrak kulit batang mangrove A. marina terhadap pertumbuhan S. aureus. data yang ditampilkan adalah data numerik berupa persentase daya hambat masing-masing konsentrasi ekstrak kulit batang mangrove A. marina dan pada sediaan krim ekstrak kulit batang mangrove A. marina pada kelompok uji F1, F2, dan F3.

\section{HASIL DAN PEMBAHASAN}

\subsection{Preparasi Sampel}

Pada penelitian ini kulit batang mangrove A. marina diambil dari salah satu wilayah di Kabupaten Cilacap tepatnya di tempat wisata hutan payau cilacap, Jawa Tengah. Kulit batang mangrove A. marina yang diambil yaitu dari bagian batang pohon segar yang sudah tua berwarna coklat.

Hasil determinasi menunjukkan bahwa tumbuhan yang digunakan dalam penelitian merupakan rimpang dari famili Avicenniaceae, Specimen Avicennia marina (Forssk.) verh. Selanjutnya, kulit batang mangrove $A$. marina yang masih segar atau masih baru dibersihkan dari kotoran dan disortir. Alasan dari pemilihan sampel kulit batang mangrove A. marina yang masih segar dan langsung dilakukan proses ekstraksi tanpa adanya pengeringan terlebih dahulu yaitu untuk mendapatkan ekstrak kental kulit batang mangrove A. marina yang baik.

\subsection{Pembuatan Ekstrak Kulit Batang Mangrove A. marina}

Hasil ekstraksi maserasi dari sampel ekstrak kulit batang mangrove A. marina sebanyak 500 gram menghasilkan ekstrak kental yang berwarna hijau kehitaman sebesar 39,41 gram, dengan nilai rendemen sebesar 7,88\%.

\subsection{Penetapan Kadar Air}

Penetapan kadar air bertujuan untuk mengetahui kualitas bahan yang digunakan atas kandungan air yang terkandung dalam suatu sampel. Hal ini dikarenakan air merupakan media tumbuh dan berkembangnya jamur. Berdasarkan nilai batas persyaratan untuk kadar air yang terkandung dalam baku simplisia dengan range yaitu ekstrak kering kadar air < $5 \%$,ekstrak kental 5-10\% dan ekstrak cair > $20 \%$ [10]. Berdasarkan hasil perhitungan kadar air terhadap ekstrak kulit batang mangrove A. marina didapatkan nilai sebesar $8 \%$. Sehingga dapat diketahui bahwa ekstrak kulit batang mangrove A. marina cukup aman dari kontaminasi jamur selama penyimpanan.

\subsection{Uji Bebas Etanol Ekstrak Kulit Batang Mangrove A. marina}

Berdasarkan hasil penelitian, didapatkan tidak timbulnya bau ester dari hasil reaksi esterifikasi yang dilakukan. Menunjukkan bahwa tidak terbentuknya senyawa aspirin. Skrining Fitokimia Ekstrak Kulit Batang Mangrove A. marina

Identifikasi kandungan senyawa aktif dalam ekstrak yang dilakukan dengan menggunakan uji tabung (melihat warna dan endapan). Hasil uji skrining fitokimia ekstrak kulit batang mangrove A. marina seperti disajikan tabel berikut :

\section{Tabel II. Hasil Skrining Fitokimia Ekstrak Kulit Batang A.marina}




\begin{tabular}{|c|c|c|c|c|}
\hline NO. & Uji Fitokimia & Pereaksi & Standar warna & Hasil \\
\hline 1. & Alkaloid & $\begin{array}{c}\mathrm{HCl} \text {, Reagen } \\
\text { Dragendroff }\end{array}$ & Orange / Merah & + \\
\hline 2. & Terpenoid & $\begin{array}{l}\text { Kloroform, } \\
\mathrm{H}_{2} \mathrm{SO}_{4}\end{array}$ & Merah Kecoklatan & + \\
\hline 3. & Tanin & $\mathrm{FeCl}_{3}$ & $\begin{array}{c}\text { Hijau hingga Biru } \\
\text { kehijauan }\end{array}$ & + \\
\hline 4. & Saponin & $\begin{array}{c}\text { Ditambahkan Air } \\
\text { Panas }\end{array}$ & $\begin{array}{c}\text { Terbentuknya } \\
\text { Buih }\end{array}$ & + \\
\hline 5. & Flavonoid & $\begin{array}{c}\operatorname{logam~Mg}, \mathrm{HCl} \\
\text { pekat }\end{array}$ & Merah / Jingga & - \\
\hline
\end{tabular}

Keterangan: (+) positif : Terdeteksi mengandung senyawa

( - ) negatif : Terdeteksi tidak mengandung senyawa.

\subsection{Uji Aktivitas Antibakterti Ekstrak Kulit Batang Mangrove A. marina}

Formulasi modifikasi yang digunakan untuk membuat sediaan krim Ekstrak Kulit Batang Mangrove A. marina ditunjukan pada Tabel dibawah berikut :

Tabel III. Hasil Uji Daya Hambat

\begin{tabular}{ccc}
$\begin{array}{c}\text { Konsentrasi Ekstrak } \\
(\%)\end{array}$ & $\begin{array}{c}\text { Diameter Zona } \\
\text { Hambat }(\mathbf{m m})\end{array}$ & Keterangan \\
\hline 2 & - & Tidak ada \\
4 & - & Tidak ada \\
6 & 12 & Kuat \\
8 & 15 & Kuat \\
10 & 20 & Kuat \\
Kontrol Positif & 22 & Sangat Kuat \\
Kontrol Negatif & - & Tidak ada \\
\hline
\end{tabular}

Hasil pengukuran diameter zona hambat ini nantinya konsentrasi ekstrak kulit batang mangrove A. marina terbaik akan digunakan sebagai bahan aktif pada formulasi krim ekstrak kulit batang mangrove $A$. marina. Zona hambat paling baik pada konsentrasi ekstrak sebesar $10 \%$ dengan diameter $(20 \mathrm{~mm})$.

\subsection{Evaluasi Karakteristik Fisik Krim}


Pada pembuatan krim konsentrasi ekstrak yang diambil setelah melakukan uji daya hambat bakteri adalah $10 \%$ untuk semua formulasi yang selanjutnya dibuat dan dilakukan evaluasi karakteristik krim.

a. Uji Organoleptis

Tabel IV. Hasil Uji Organoleptis

\begin{tabular}{cccc}
\hline \multirow{2}{*}{ Evaluasi } & \multicolumn{3}{c}{ Sediaan Krim } \\
\cline { 2 - 4 } & F1 & F2 & F3 \\
\hline Warna & Putih Cokelatan & Putih Cokelatan & Putih Cokelatan \\
Bentuk & Semisolid & Semisolid & Semisolid \\
Bau & Khas & Khas & Khas \\
\hline
\end{tabular}

Hasil uji pengamatan secara organoleptis menunjukkan bahwa krim ekstrak kulit batang mangrove A. marina dengan konsentrasi ekstrak $10 \%$ dan variasi komposisi jumlah propilenglikol F1 (2 gram), F2 (3 gram) dan F3 (4 gram) tidak menghasilkan perbedaan warna pada krim. Tidak adanya Perbedaan warna disebabkan karena konsentrasi penambahan ekstrak sama. Selanjutnya bau dan bentuk dari sediaan krim memiliki bau khas mangrove yang sama serta bentuk yang sama.

\section{b. Uji Homogenitas Krim}

Hasil pengujian homogenitas menunjukkan bahwa krim ekstrak kulit batang mangrove A. marina F1, F2 dan F3 menunjukan susunan yang homogen, ditandai dengan warna sediaan krim merata tidak terdapat partikel-partikel yang menggumpal. Uji homogenitas sediaan krim ekstrak kulit batang mangrove A. marina menunjukkan bahwa krim tetap homogen dan tidak ada terjadinya pemisahan dari sediaan krim.

\section{c. Uji Daya Sebar}

Persyaratan daya sebar untuk sediaan topikal yaitu sekitar 5-7 cm atau 19,62-38,46 $\mathrm{cm}^{2}$. Kemampuan sebaran yang baik ketika diaplikasikan di kulit dapat membantu sediaan dalam meratakan zat aktif agar memaksimalkan efektivitasannya serta dapat diabsorpsi dengan cepat oleh kulit [11]. Hasil uji daya sebar menunjukan bahwa setiap formulasi memiliki daya sebar yang berbeda-beda yang disebabkan oleh pengaruh dari ekstrak. Sediaan yang memiliki daya sebar paling besar yaitu pada F3 dengan rata-rata daya sebar sebesar $4,53 \mathrm{~cm}$, sedangkan pada F2 memiliki rata-rata daya sebar sebesar $3,53 \mathrm{~cm}$, dan F1 sebesar 2,69 $\mathrm{cm}$.

\section{d. Uji pH}

Hasil uji pH krim ekstrak kulit batang mangrove A. marina ketiga formulasi yaitu F1, F2 dan F3 memiliki pH yang sama yaitu 6. Dari hasil tersebut dapat disimpulkan bahwa sediaan krim ekstrak kulit batang mangrove A. marina memiliki nilai dengan rentang $\mathrm{pH}$ yang sesuai seperti pada literatur penelitian sebelumnya [12].

\section{e. Uji Daya Lekat}

Nilai standar uji daya lekat yaitu tidak boleh $<0,07$ menit atau $<4$ detik [9]. Hasil uji daya lekat pada formulasi 1 memiliki rata-rata yaitu 25,20 detik pada formulasi 2 memiliki rata-rata 13,16 detik dan formulasi 3 memiliki rata-rata 09,26 detik dapat disimpulkan Hasil uji viformulasi 1, 2 dan 3 tidak memenuhi standar karena $<4$ detik. 


\section{f. Uji Viskositas}

Hasil uji viskositas menunjukan bahwa setiap formulasi sediaan krim ekstrak kulit batang mangrove A. marina F1, F2 dan F3 memiliki viskositas yang berbeda. Selain itu penambahan propilenglikol pada formulasi dapat meningkatkan viskositas, karena propilenglikol mampu menarik air yang menyebabkan kulit terhidrasi dan menjadi lembab [13]. Ketiga formulasi krim ekstrak kulit batang mangrove A. marina memenuhi nilai strandar (cPs) yaitu 4000 - 40.000. dari ketiga formulasi krim ekstrak kulit batang mangrove A. marina nilai setandar (cPs) paling tinggi pada sediaan $\mathrm{F} 3$ hal ini menunjukan bahwa jumlah propilenglikol yang lebih besar mempengaruhi tingginya nilai viskositas.

\section{g. Uji Tipe Krim}

Hasil uji tipe krim pada sediaan krim ekstrak kulit batang mangrove A. marina pada F1, F2 dan F3 menunjukan tipe krim yang sama yaitu krim tipe minyak dalam air ( M / A).

\subsection{Uji Aktivitas Antibakteri Sediaan Krim Ekstrak Kulit Batang Mangrove A. marina}

Hasil rata-rata diameter zona hambat dari ketiga formulasi sama yaitu F1 ( $23 \mathrm{~mm}$ ), F2 ( $23 \mathrm{~mm}$ ), F3 ( $23 \mathrm{~mm}$ ) dan kontrol positif ( $21 \mathrm{~mm}$ ). Hal ini dikarenakan pada ke 3 formulasi Sediaan Krim Ekstrak Kulit Batang Mangrove A. marina memiliki konsentrasi jumlah ekstrak yang sama yaitu 10\%. Sedangkan pada kontrol (-) tidak memiliki zona hambat karena hanya menggunakan basis krim dan tidak menggunakan ekstrak. Semuanya memiliki kategori zona hambat sangat kuat. Range dikatakan lemah jika diameter zona hambat $<5 \mathrm{~mm}$, dikatakan sedang yaitu $5-10 \mathrm{~mm}$, kuat $10-20 \mathrm{~mm}$ dan dikatakan sangat kuat jika $>20 \mathrm{~mm}$ [10]. Hat tersebut dapat dilihat bahwa ekstrak kulit batang mangrove Avicennia marina dapat menghambat pertumbuhan bakteri Staphylococcus aureus dan serupa dengan penelitian sebeulmnya daya hambat ekstrak tergolong kuat [12].

\section{KESIMPULAN}

Formulasi krim ekstrak kulit batang mangrove A. marina dengan variasi komposisi jumlah propilenglikol yaitu F1 sebanyak 2 gram, F2 sebanyak 3 gram dan F3 sebanyak 4 gram pada sediaan krim ekstrak kulit batang mangrove A. marina. Formulasi sediaan krim ekstrak kulit batang mangrove A. marina dilakukan evaluasi karteristik fisik krim untuk mengetahui kesetabilan mutu sediaan krim ekstrak kulit batang mangrove A. marina, hasilnya yaitu pada uji organoleptis dari ketiga formulasi memiliki warna, bau dan bentuk yang sama dan hanya berbeda di tekstur pada F3 teksturnya lebih encer. Hasil uji homogenitas, uji viskositas dan uji pH sediaan dari ketiga sediaan memenuhi persaratan. Sedangkan pada uji daya sebar dan uji daya lekat tidak sesuai setandar. Formulasi sediaan krim ekstrak kulit batang mangrove A. marina yaitu F1, F2 dan F3 memiliki aktivitas antibakteri yang sama terhadadap pertumbuhan bakteri S. aureus dengan rata-rata diameter zona hambat sebesar $23 \mathrm{~mm}$, sedangkan pada kontrol positif rata-rata diameter zona hambatnya yaitu $21 \mathrm{~mm}$ dan pada kontrol negatif tidak terdapat zona bening atau zona hambat.

\section{DAFTAR PUSTAKA}

[1] Maksumah, Anggun., Balfas, Rifqi Ferry., Fajarini, Hanari., Yulianto, Iqbal. Uji Efektivitas Sediaan Gel Sabun Wajah Ekstrak Daun Kemangi (Ocimum Basilicum L.) Terhadap 
Bakteri Staphylococcus aureus. Jurnal Ilmiah Jophus : Journal of Pharmacy UMUS, Vol. 2 No. 02, Februari 2021, [Online]

[2] Kordi GH, Ekosistem Mangrove: Potensi, Fungsi, dan Pengelolaan, 2012, Jakarta : Penerbit Rineka Cipta.

[3] Renaldi,dkk, "Bioaktivitas Senyawa Bioaktif Pada Mangrove Avicennia Marina Dan Bruguiera Gymnorrhiza Sebagai Antibakteri Yang Diambil Dari Pulau Payung Dan Tanjung Api-Api” Jurnal Universitas Sriwijaya, Indralaya, Indonesia, 2018 , [Online]

[4] Atmoko AD, Anom P, "Formulasi Bentuk Sediaan Krim Ekstrak Daun Sirih (Piper Betle Linn) Hasil Isolasi Metode Maserasi Etanol 90\%”, Indonesian Journal on Medical Science, Vol.1(2), 2014, [Online]

[5] Marliana, S.D., Saleh, C, "Uji Fitokimia dan Aktivitas Antibakteri Ekstrak Kasar Etanol, Fraksi nHeksana, Etil asetat, dan Metanol dari Buah Labu Air (Lagenari Siceraria (Morliana)", Jurnal Kimia Mulawarman, Vol. 8(2): 39-63, 2011 , [Online]

[6] Haryati, N.A., C.S. Erwin, "Uji Toksisitas dan Aktivitas Antibakteri Ekstrak Daun Merah (Syzygium mytifolium Walp) terhadap Bakteri Staphylococus aureus dan Escherichia coli”, Jurnal Kimia Mulawarman, Vol.13(1): 35-39, 2015 , [Online]

[7] Sangi, M., M.R.J. Runtuwene., H.E.I. Simbala, dan V.M.A. Makang, “Analisis Fitokimia Tumbuhan Obat di Kabupaten Minahasa Utara", Chem. Prog, Vol 1(1): 47-53, 2008 , [Online]

[8] Sari, D. E. M., \& Ernanda, T. H, "Uji Aktivitas Antioksidan Krim Ekstrak Daun Mengkudu ( Morinda Citrifolia L.) Berbasis Vanishing Cream”. Jurnal Ilmiah JOPHUS : Journal Of Pharmacy UMUS, Vol. 3(01), 10-18, 2021, [Online] Available : https://doi.org/10.46772/jophus.v3i01.519

[9] Voigt, R, Buku Pelajaran Teknologi Farmasi Edisi Kelima, diterjemahkan oleh Drs. Soendani Noerono, 1994, Yogyakarta: Gadjah Mada University Press.

[10] Saraswati, A., "Efektivitas Ekstrak Daun Teh Hijau (Camellia sinensis) Dengan NaOCl 2,5\% Terhadap Bakteri Enterococcus faecalis Sebagai Alternatif Lautan Irigasi Saluran Akar", Skripsi., Fakultas Kedokteran Ggi Universitas Hasanudin., Makassar, 2015, [Online]

[11] Ulaen, Selfie P.J., Banne, Suatan, Y., dan Ririn A, "Pembuatan Salep Anti Jerawat dari Ekstrak Rimpang Temulawak (Curcuma xanthorrhiza Roxb.)", Jurnal Ilmiah Farmasi, Vol.3(2): 45-49, 2012, [Online]

[12] Saputra, Eko., Setiyabudi, Lulu. ., Issusilaningtyas, E, "Pengaruh Konsentrasi Ekstrak Kulit Batang Mangrove (Avicennia Marina) Dalam Sediaan Krim Terhadap Sifat Fisik Dan Aktivitas Antibakteri Staphylococcus aureus", Jurnal Ilmiah JOPHUS : Journal Of Pharmacy UMUS, Vol. 2 No. 02. Februari 2021, [Online]

[13] Ningsih W, Firmansyah, Fitri H, "Formulasi masker peel off dengan beberapa konsentrasi ekstrak etanol buah naga super merah (Hylocereus costaricensis (F.A.C Weber) Britton \& Rose)", Scientia., Vol.6(1):18-24, 2016, [Online] 